Bangladesh J. Plant Taxon. 19(2): 191-200, 2012 (December)

(C) 2012 Bangladesh Association of Plant Taxonomists

\title{
POLLEN MORPHOLOGY OF BEGONIA L. (BEGONIACEAE) IN NEPAL
}

\author{
Sangeeta Rajbhandary ${ }^{1}$, Mark Hughes ${ }^{2}$ and Krishna K. Shrestha \\ Central Department of Botany, Tribhuvan University, Kirtipur, Kathmandu, Nepal \\ Keywords: Begonia L.; Nepal; Pollen morphology; SEM.
}

\begin{abstract}
The pollen morphology of 28 Begonia species of Nepal has been examined by scanning electron microscopy (SEM). Comparative pollen analysis was made based on size, shape in polar and equatorial views, P/E ratio, aperture, and exine ornamentation. In this study, four types of pollen ornamentation morphology have been identified. Among Nepalese Begonia, B. roxburghii (section Sphenanthera) has the smallest pollen (11.2$12.8 \times 6.4-7.0 \mu \mathrm{m})$ and B. flagellaris (section Diploclinium) has the largest pollen (24.3$30.6 \times 11.4-12.0 \mu \mathrm{m}$ ). Presence of margo in the pollen ornamentation is a distinguishing character that separates Begonia section Platycentrum from all other sections of Nepalese Begonia.
\end{abstract}

\section{Introduction}

The genus Begonia L. (Begoniaceae) is the sixth largest genus of flowering plants (Frodin, 2004). The genus was previously represented by 18 species in Nepal (Hara et al., 1978; Doorenbos et al., 1998; Press et al., 2000), one new record (Rajbhandary and Shrestha, 2009) and three new species (Rajbhandary et al., 2010) bring the current number of Begonia species known from the country to 22. There are seven endemic species in Nepal: B. tribenensis C.R. Rao, $B$. minicarpa $\mathrm{H}$. Hara, B. flagellaris H. Hara, B. leptoptera H. Hara, B. nuwakotensis S. Rajbhandary, B. panchtharensis S. Rajbhandary and B. taligera S. Rajbhandary. Nepalese Begonia are placed within five different sections: Diploclinium (Lindl.) A.DC., Monopteron (A.DC.) Warb., Platycentrum (Klotzsch) A.DC., Putzeysia (Klotzsch) A.DC. and Sphenanthera (Hassk.) Warb. (Smith et. al., 1986; Doorenbos et al., 1998).

The variation in ultrastructural characteristics and surface morphology of pollen grains is often of valuable assistance in delimiting taxonomic relationships, particularly at higher taxonomic ranks for family level: Euphorbiaceae (Perveen and Qaiser, 2005), Tiliaceae, Sterculiaceae and Malvaceae (Husseini, 2006), Cucurbitaceae (Perveen and Qaiser, 2008), Campanulaceae (Erkara et al., 2008), for generic level in Sambucus (Tamas et al., 2009), but also between species as in Pedicularis (Bano et al., 2012). Scanning electron microscopy (SEM) is a valuable tool which can reveal many of these taxonomically useful characters, and have the potential to reveal relationships that are obscure and difficult to demonstrate by other means.

Although pollen morphology is important in taxonomic research, very few studies have been carried out in this regards on Begonia species. Erdtman (1966) noted the small size, the prolate and perprolate shape of the Begonia pollen and a very thin exine which did not show much stratification. Van Den Berg (1985) carried out an SEM study of the pollen morphology of African Begonia to shed light on sectional delimitation in the genus. There has been no study regarding both American and Asian species, including Nepalese Begonia. In some works on pollen morphology (Wodehouse, 1935; Erdtman, 1966) a few of the indigenous plants of Southeast Asia

\footnotetext{
${ }^{1}$ Corresponding author. Email: imogine3@gmail.com

${ }^{2}$ Royal Botanic Garden Edinburgh, 20a Inverleith Row, Edinburgh EH3 5LR, United Kingdom.
} 
have been described, but none from mainland Asia or Nepal. Recognition of pollen types may lead to a better understanding of the relationships of the taxa within the genus (Van Den Berg, 1984). The objective of this paper is to provide a detailed account of the pollen morphology of Nepalese Begonia as highlighted through SEM.

\section{Materials and Methods}

Pollen of 28 Begonia species in Nepal belonging to four sections, namely Diploclinium, Monopteron, Platycentrum and Sphenanthera were examined from the herbarium specimens collected in Nepal and deposited in TUCH, KATH, E, and K herbaria. Due to lack of male flowers on specimens of Begonia gemmipara (section Putzeysia), the pollen morphology of this species could not be studied. Morphological variation in pollen includes the size, $\mathrm{P} / \mathrm{E}$ ratio, aperture and ornamentation (Table 1).

Pollen data obtained in this study are based on observations using SEM. Pollen grains were mounted on Agar Scientific adhesive carbon tabs $12 \mathrm{~mm}$ in size placed on Aluminium stubs. The pollen on the stubs was then sputter-coated with $250 \mathrm{~nm}$ platinum particles using an Emitech K575X sputter coater at one runs of 2 min. The prepared specimens were examined in a LEO Supra 55VP Scanning Electron Microscope at a voltage of $5 \mathrm{kV}$ and a working distance $6 \mathrm{~mm}$. The SEM images were captured at a resolution of $2048 \times 1536$ pixel and saved in TIF format. The SEM was carried out at the Royal Botanic Garden Edinburgh, UK.

\section{Results and Discussion}

The pollen grains in Begonia are single, isopolar and 3-zono-colporate (Fig. 1a-b). The shape ranges from prolate to perprolate and the polar axis measures from 11.2-28.9 $\mu \mathrm{m}$ and the equatorial diameter from 1.7-3.1 $\mu \mathrm{m}$. The outline of Begonia pollen is mostly somewhat elliptic. The long sides though usually convex, can be straight or even concave, the poles can be rounded or somewhat pointed. The outline in the polar view can be either circular (B. flagellaris Fig. 2 AB; B. minicarpa Fig 4. M-N; B. flaviflora Fig. 5 C-D) or triangular with interaxillary apertures in majority of species. The ecto-apertures are very long and closed by a granular colpus membrane. The striate ornamentation continues up to the margin of the colpus and in some species a margo of deviating not-striate ornamentation is present along the colpus.

The pollen of B. anisanthera ined., B. manangiensis ined., B. cathcartii, B. flaviflora and B. roxburghii are prolate while rest of the taxa studied have perprolate pollen (Table 1). Among Nepalese Begonia, B. roxburghii (section Sphenanthera) has the smallest pollen (11.2-12.8 $\times 6.4$ $7.0 \mu \mathrm{m})$ and B. flagellaris (section Diploclinium) has the largest pollen (24.3-30.6 × 11.4-12.0 $\mu \mathrm{m})$. The shape and type of aperture in the pollen grains in the Begonia species studied proved to be of little systematic significance, as most of the species have perprolate pollen with only a few species having prolate pollen. Even so, within the taxa and even within the samples a certain amount of variability is still encountered, especially in size, shape, and apertures.

The nature of surface ornamentation is the most important feature which is of systematic significance. The sculpture on the surface of the grains is formed by a pattern of exine elements separated by spaces. The exine elements are called muri. The striate pattern shown by Begonia pollen can be defined as a regular pattern of approximately parallel muri. More in particular in striate grains or the ridges of exineous material, is termed as lirae and the grooves in-between the ridges as striate (Van Den Berg, 1984). Depending on the width of the lirae and striae, the striate pattern can be designated as finely or coarsely striate. A number of minute perforations are present 
Table 1. Comparison in pollen size, aperture and ornamentation of 28 Begonia taxa in Nepal.

\begin{tabular}{|c|c|c|c|c|c|c|}
\hline \multirow{2}{*}{$\begin{array}{l}\text { Sl. } \\
\text { No }\end{array}$} & \multirow[t]{2}{*}{ Species } & \multicolumn{2}{|c|}{ Pollen size $(\mu \mathrm{m})$} & \multirow[t]{2}{*}{ P/E Ratio } & \multirow[t]{2}{*}{ Aperture } & \multirow[t]{2}{*}{ Ornamentation } \\
\hline & & $\mathrm{P}(\mu \mathrm{m})$ & $E(\mu \mathrm{m})$ & & & \\
\hline \multicolumn{7}{|c|}{ Section Diploclinium } \\
\hline 1. & $\begin{array}{l}\text { B. anisanthera S. } \\
\text { Rajbhandary ined. }\end{array}$ & $13.6-13.8$ & $7.2-7.4$ & $1.8-1.9$ & prolate & coarsely striate \\
\hline 2. & $\begin{array}{l}\text { B. bryophila S. } \\
\text { Rajbhandary ined. }\end{array}$ & 21.6-22.8 & $9.3-10$ & 2.3-2.5 & perprolate & coarsely striate \\
\hline 3. & $\begin{array}{l}\text { B. dioica Buch.-Ham ex } \\
\text { D. Don }\end{array}$ & $24.2-26.2$ & 9.4 & $2.6-2.8$ & perprolate & $\begin{array}{l}\text { fine faint striate } \\
\text { ornamentation with } \\
\text { pores }\end{array}$ \\
\hline 4. & $\begin{array}{l}\text { B. dolichoptera S. } \\
\text { Rajbhandary ined. }\end{array}$ & 23.8-24.8 & $10.2-10.4$ & 2.3-2.4 & perprolate & $\begin{array}{l}\text { fine faint striate } \\
\text { ornamentation with } \\
\text { pores }\end{array}$ \\
\hline 5. & B. flagellaris H. Hara & 24.3-30.6 & $11.4-12$ & $2.0-2.6$ & perprolate & coarsely striate \\
\hline 6. & B. josephii A. DC. & 24.8 & 9.8 & 2.5 & perprolate & $\begin{array}{l}\text { fine faint striate } \\
\text { ornamentation with } \\
\text { pores }\end{array}$ \\
\hline 7. & B. leptoptera H. Hara & 26.0 & $8.6-9.4$ & $2.7-3.0$ & perprolate & $\begin{array}{l}\text { fine faint striate } \\
\text { ornamentation with } \\
\text { pores }\end{array}$ \\
\hline 8. & $\begin{array}{l}\text { B. manangiensis S. } \\
\text { Rajbhandary ined. }\end{array}$ & $19.6-20.8$ & $9.4-10.4$ & 2.1 & prolate & coarsely striate \\
\hline 9. & B. minicarpa H. Hara & $17.4-18.2$ & 7.6-8.0 & $2.2-2.3$ & perprolate & $\begin{array}{l}\text { fine faint striate } \\
\text { ornamentation with } \\
\text { pores }\end{array}$ \\
\hline 10 & $\begin{array}{l}\text { B. oedotheca S. } \\
\text { Rajbhandary \& K.K. } \\
\text { Shrestha ined. }\end{array}$ & $22.0-23.0$ & 11.0 & $2.0-2.1$ & perprolate & coarsely striate \\
\hline 11. & B. ovatifolia A. DC. & 18.4 & $6.8-7.2$ & $2.5-2.7$ & perprolate & fine striate \\
\hline 12. & B. picta $\mathrm{Sm}$. & $22.0-23.2$ & 7.4 & 2.9-3.1 & perprolate & $\begin{array}{l}\text { fine faint striate } \\
\text { ornamentation with } \\
\text { pores }\end{array}$ \\
\hline 13. & $\begin{array}{l}\text { B. rubella Buch.-Ham. ex } \\
\text { D. Don }\end{array}$ & 17.6-21.6 & 7.4-8.6 & $2.3-2.5$ & perprolate & fine striate \\
\hline 14. & $\begin{array}{l}\text { B. sinwaensis S. } \\
\text { Rajbhandary ined. }\end{array}$ & 20.8-21.9 & $8.2-8.8$ & 2.4-2.7 & perprolate & coarsely striate \\
\hline 15. & $\begin{array}{l}\text { B. staintonii S. } \\
\text { Rajbhandary \& K.K. } \\
\text { Shrestha ined. }\end{array}$ & $25-26$ & 11.0 & 2.3-2.4 & perprolate & $\begin{array}{l}\text { fine faint striate } \\
\text { ornamentation with } \\
\text { pores }\end{array}$ \\
\hline 16. & B. tribenensis C.R. Roa & 19.6-21.4 & 7.5-8.9 & 2.4-2.6 & perprolate & fine striate \\
\hline \multicolumn{7}{|c|}{ Section Platycentrum } \\
\hline 17. & B. annulata K. Koch. & $19.4-23.0$ & $8.6-9.75$ & $2.2-2.3$ & perprolate & $\begin{array}{l}\text { fine striate with } \\
\text { margo }\end{array}$ \\
\hline 18. & $\begin{array}{l}\text { B. cathcartii Hook. f. \& } \\
\text { Thomson }\end{array}$ & $17.4-17.6$ & 9.2 & $1.8-1.9$ & prolate & $\begin{array}{l}\text { coarsely striate } \\
\text { with margo }\end{array}$ \\
\hline 19. & B. flaviflora $\mathrm{H}$. Hara & $14.4-19.5$ & $8.4-10.0$ & $1.7-1.9$ & prolate & $\begin{array}{l}\text { coarsely striate } \\
\text { with margo }\end{array}$ \\
\hline 20. & $\begin{array}{l}\text { B. hatacoa Buch.-Ham. } \\
\text { ex D. Don }\end{array}$ & $16.0-18.6$ & 8.0 & $2.0-2.3$ & perprolate & $\begin{array}{l}\text { fine striate with } \\
\text { margo }\end{array}$ \\
\hline
\end{tabular}


Table 1 Contd.

\begin{tabular}{|c|c|c|c|c|c|c|}
\hline \multirow{2}{*}{$\begin{array}{l}\text { Sl } \\
\text { No }\end{array}$} & \multirow[t]{2}{*}{ Species } & \multicolumn{2}{|c|}{ Pollen size $(\mu \mathrm{m})$} & \multirow[t]{2}{*}{ P/E Ratio } & \multirow[t]{2}{*}{ Aperture } & \multirow[t]{2}{*}{ Ornamentation } \\
\hline & & $\mathrm{P}(\mu \mathrm{m})$ & $\mathrm{E}(\mu \mathrm{m})$ & & & \\
\hline \multicolumn{7}{|c|}{ Section Platycentrum } \\
\hline 21. & B. megaptera A. DC. & $23.0-23.4$ & 8.4 & $2.7-2.8$ & perprolate & $\begin{array}{l}\text { fine striate with } \\
\text { margo }\end{array}$ \\
\hline 22. & $\begin{array}{l}\text { B. nuwakotensis S. } \\
\text { Rajbhandary }\end{array}$ & $22.0-22.5$ & 7.6-8.4 & $2.7-2.8$ & perprolate & $\begin{array}{l}\text { fine striate with } \\
\text { margo }\end{array}$ \\
\hline 23. & B. palmata D. Don & 21.6-25.1 & $8.4-8.9$ & $2.6-2.8$ & perprolate & $\begin{array}{l}\text { fine striate with } \\
\text { margo }\end{array}$ \\
\hline 24. & $\begin{array}{l}\text { B. panchtharensis S. } \\
\text { Rajbhandary }\end{array}$ & $16.8-21$ & $8.0-10.0$ & 2.1 & perprolate & $\begin{array}{l}\text { fine striate with } \\
\text { margo }\end{array}$ \\
\hline 25. & B. sikkimensis A. DC. & 24.6-28.9 & $8.8-10$ & $2.6-2.8$ & perprolate & $\begin{array}{l}\text { fine striate with } \\
\text { margo }\end{array}$ \\
\hline 26. & B. taligera S. Rajbhandary & $17.4-20$ & 8.0 & $2.1-2.5$ & perprolate & $\begin{array}{l}\text { coarsely striate } \\
\text { with margo }\end{array}$ \\
\hline \multicolumn{7}{|c|}{ Section Monopteron } \\
\hline 27. & $\begin{array}{l}\text { B. nepalensis (A. DC.) } \\
\text { Warb. }\end{array}$ & $19.6-20.0$ & $8.2-8.6$ & $2.3-2.4$ & perprolate & fine striate \\
\hline \multicolumn{7}{|c|}{ Section Sphenanthera } \\
\hline 28. & $\begin{array}{l}\text { B. roxburghii (Miq.) A. } \\
\text { DC. }\end{array}$ & $11.2-12.8$ & $6.4-7.0$ & $1.7-1.8$ & prolate & fine striate \\
\hline
\end{tabular}
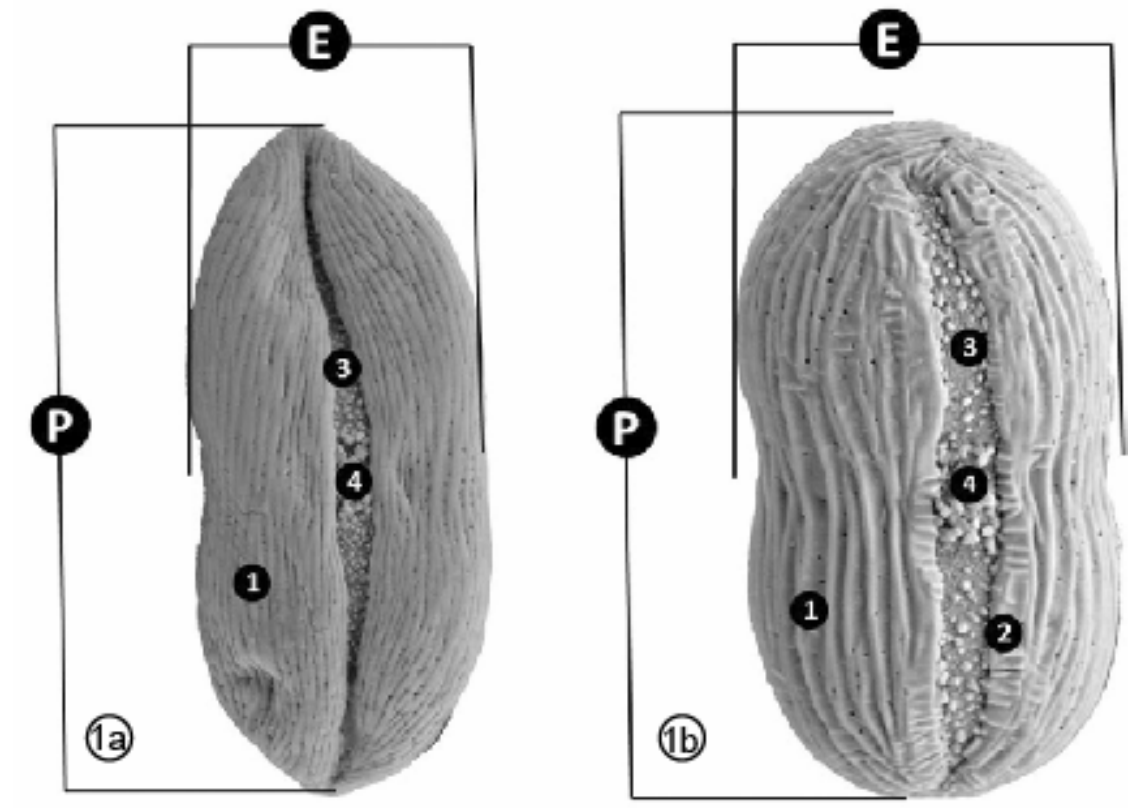

Fig. 1. General morphology of Begonia pollen equatorial view. 1a. Pollen without margo; 1b. Pollen with margo. $\mathrm{P}=$ Polar axia; $\mathrm{E}=$ equatorial diameter; $1=$ striate ornamentation; 2 = margo; $3=$ colpus membrane; 4 = endoaperture. 

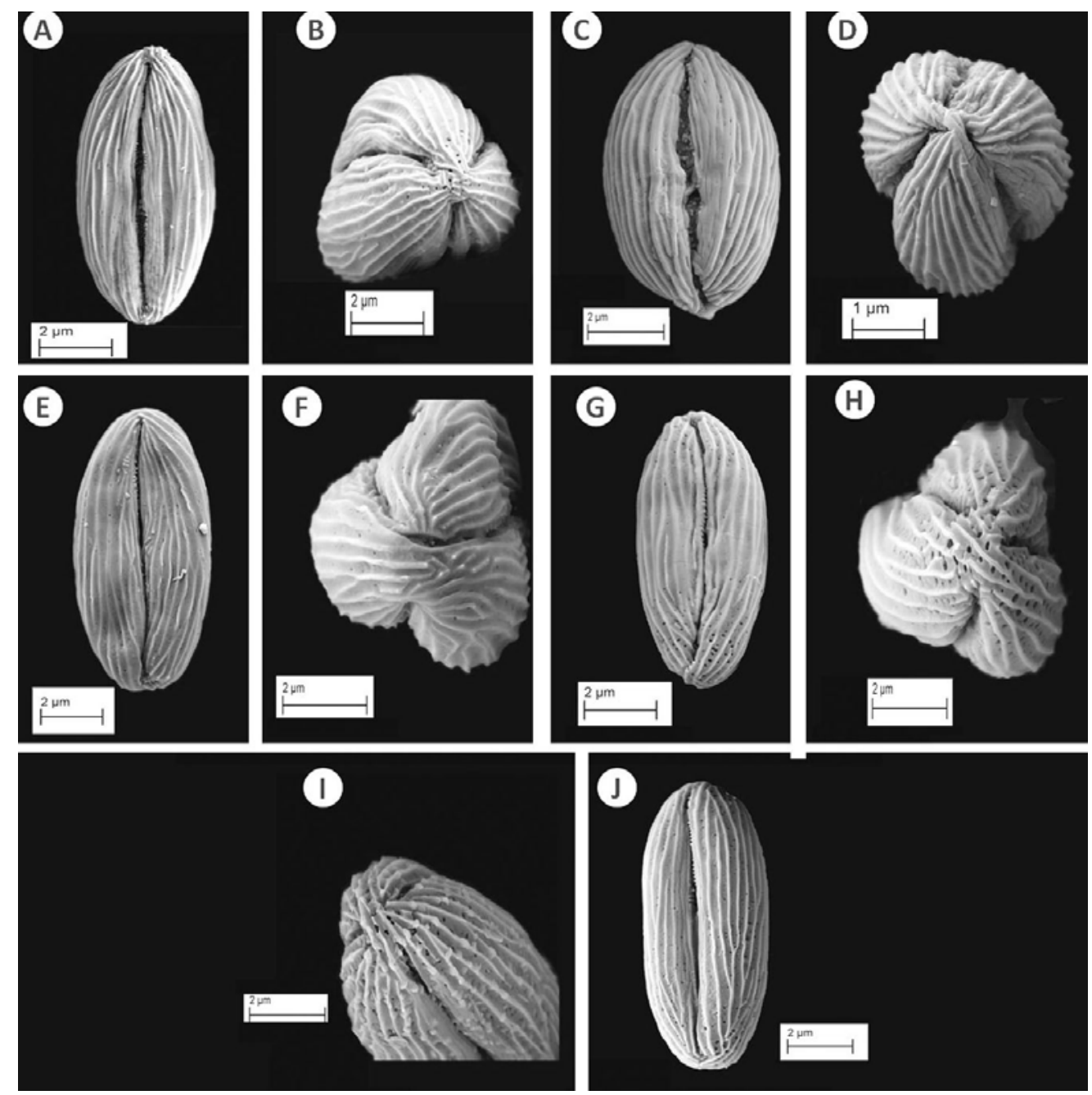

Fig. 2. Pollen with fine striate ornamentation with or without pores and absence of margo. A-B. Begonia tribenensis (Rajbhandary \& Poudyal S1); C-D. B. roxburghii (Chand 5998); E-F. B. nepalensis (Stainton 8906); G-H. B. rubella (Rajbhandary et al. S34); I-J. B. ovatifolia (Williams \& Stainton 8317).

in some species. A striking feature that was found in the pollen is the presence of a margo, which was very useful to separate Begonia sections Platycentrum from Diploclinium, Sphenanthera and Monopteron.

Within Begonia sections Diploclinium, Sphenanthera, Monopteron and Platycentrum exine ornamentation varies among species and four types of ornamentation morphology have been identified: (a) pollen with fine striate ornamentation with or without pores and absence of margo (Fig. 2); (b) pollen with coarsely striate ornamentation with few scattered pores and absence of margo (Fig. 3); (c) pollen with faint fine striate ornamentation with pores and absence of margo (Fig. 4) and (d) pollen with striate ornamentation with or without pores and presence of margo (Fig. 5). 

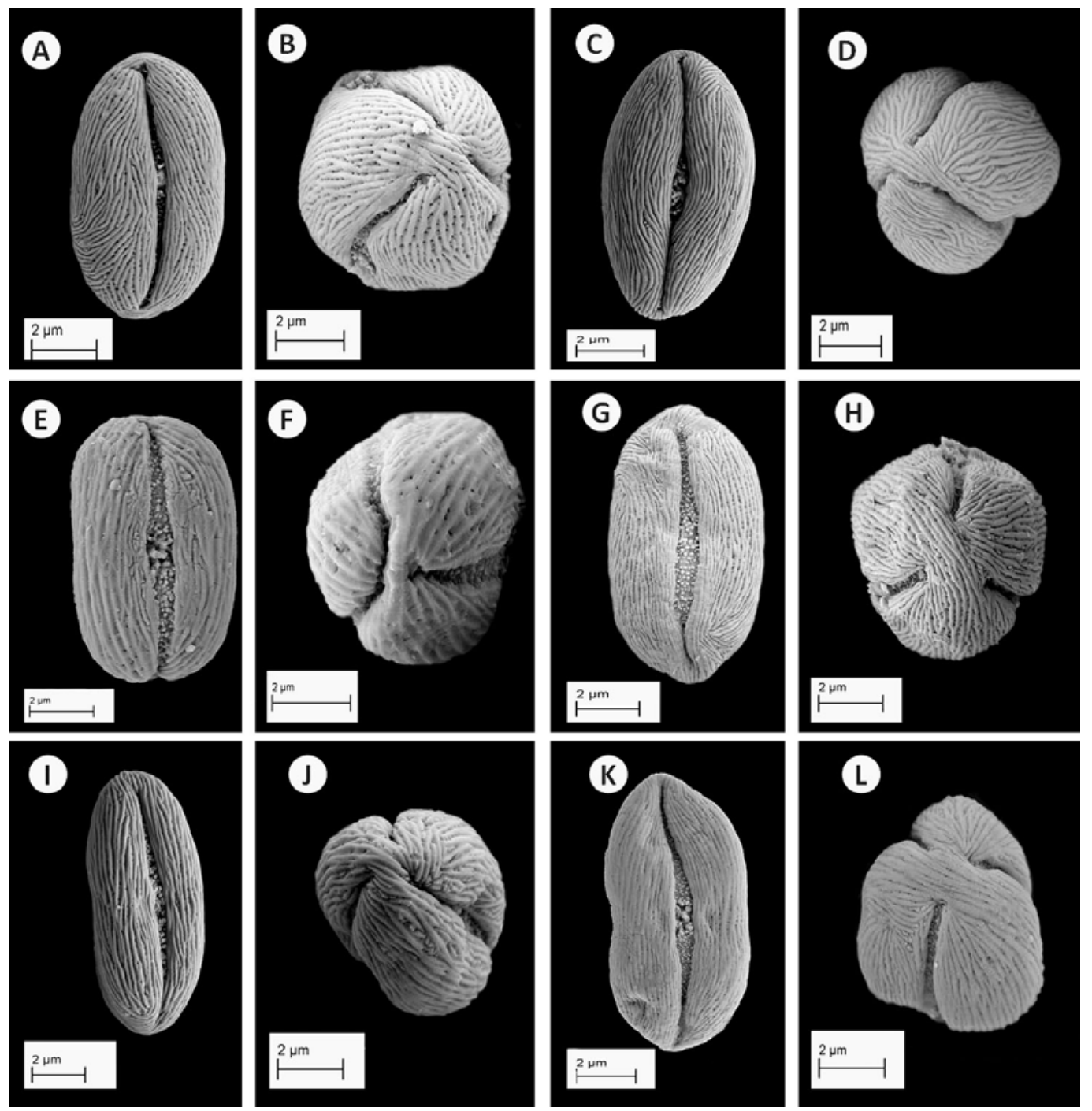

Fig. 3. Pollen with coarsely striate ornamentation with few scattered pores and absence of margo. A-B. Begonia flagellaris (Rajbhandary \& Bista 10); C-D. B. oedotheca ined. (Stainton, Sykes \& Williams 8419); E-F. B. anisanthera ined. (EMAK 6); G-H. B. manangiensis ined. (M. Mikage et al. 9470411); I-J. B. sinwaensis ined. (Rajbhandary \& Bista S43); K-L. B. bryophila ined. (Rajbhandary \& Bista S45).

There is complete absence of pores and margo (Fig. 2) in B. roxburghii (section Sphenanthera) and B. nepalensis (section Monopteron). B. tribenensis, B. rubella and B. ovatifolia have more pores near the polar region and on the poles (Fig. 2). The pores in B. dolichoptera ined. (Fig. 4 A-B) and B. josephii (Fig. 4 C-D) of section Diploclinium and in B. annulata (Fig. 5 A-B) and in B. megaptera (Fig. $5 \mathrm{G}-\mathrm{H}$ ) of section Platycentrum are larger in size and very distinct at the polar region. 

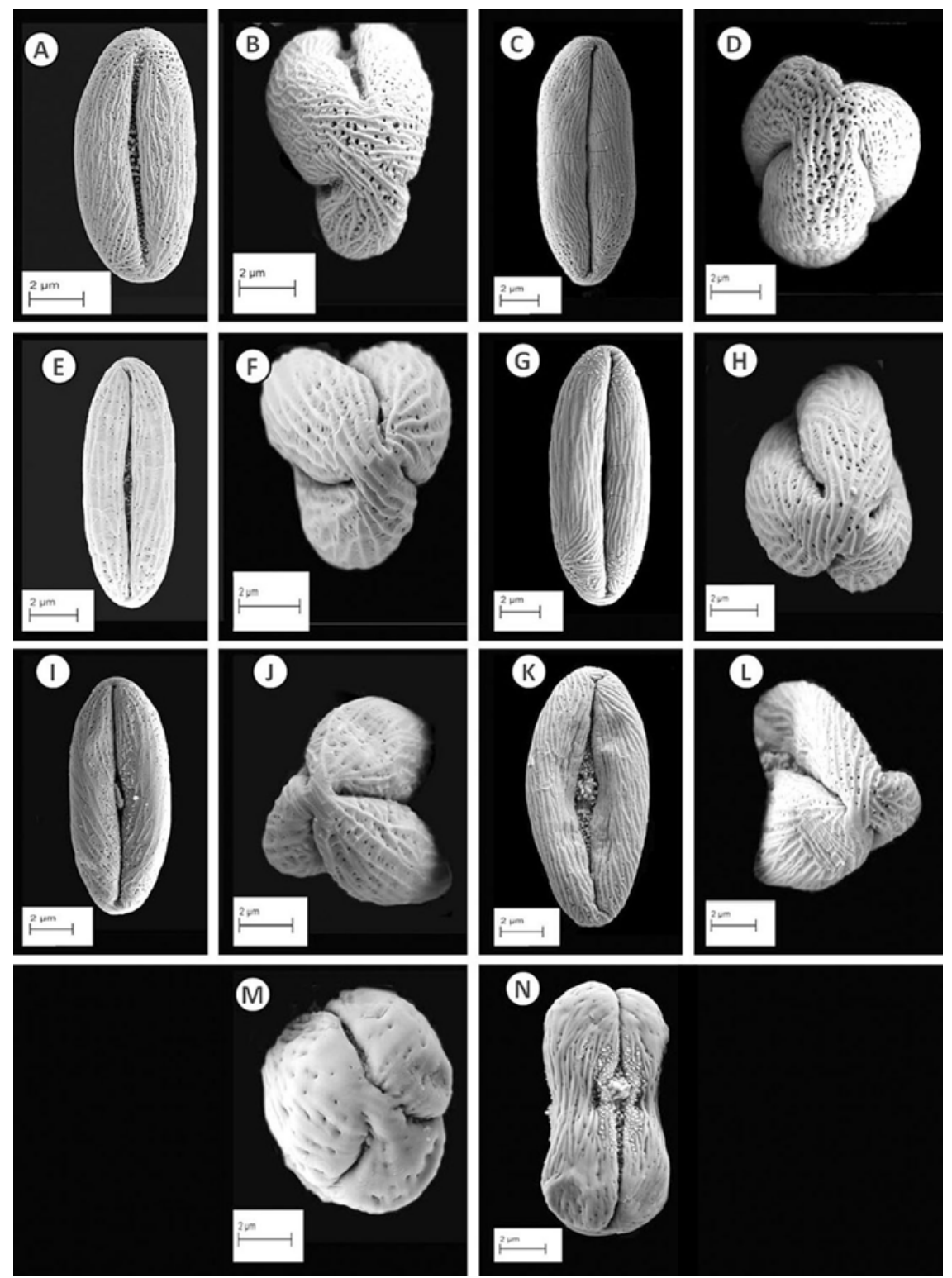

Fig. 4. Pollen with fine faint striate ornamentation with pores presented more towards the pole and absence of margo. A-B. Begonia dolichoptera ined. (KEKE 248); C-D. B. josephii (Rajbhandary \& Bista S56); E-F. B. picta (Rajbhandary \& Bista S02); G-H. B. leptoptera (Rajbhandary et al. S19).; I-J. B. dioica (Rajbhandary \& Bista S42); K-L. B. staintonii ined. (Stainton 1414); M-N. B. minicarpa (Williams \& Stainton 8319).

The pollen types sharing coarsely striate ornamentation differ in other characters such as size, shape and aperture (Fig. 3). In most of the species in this category, the ectoaperatures are very long with wide colpi and straight margin and closed by a granular colpus membrane which becomes coarser in the endo-apertural area (Fig. 3). 

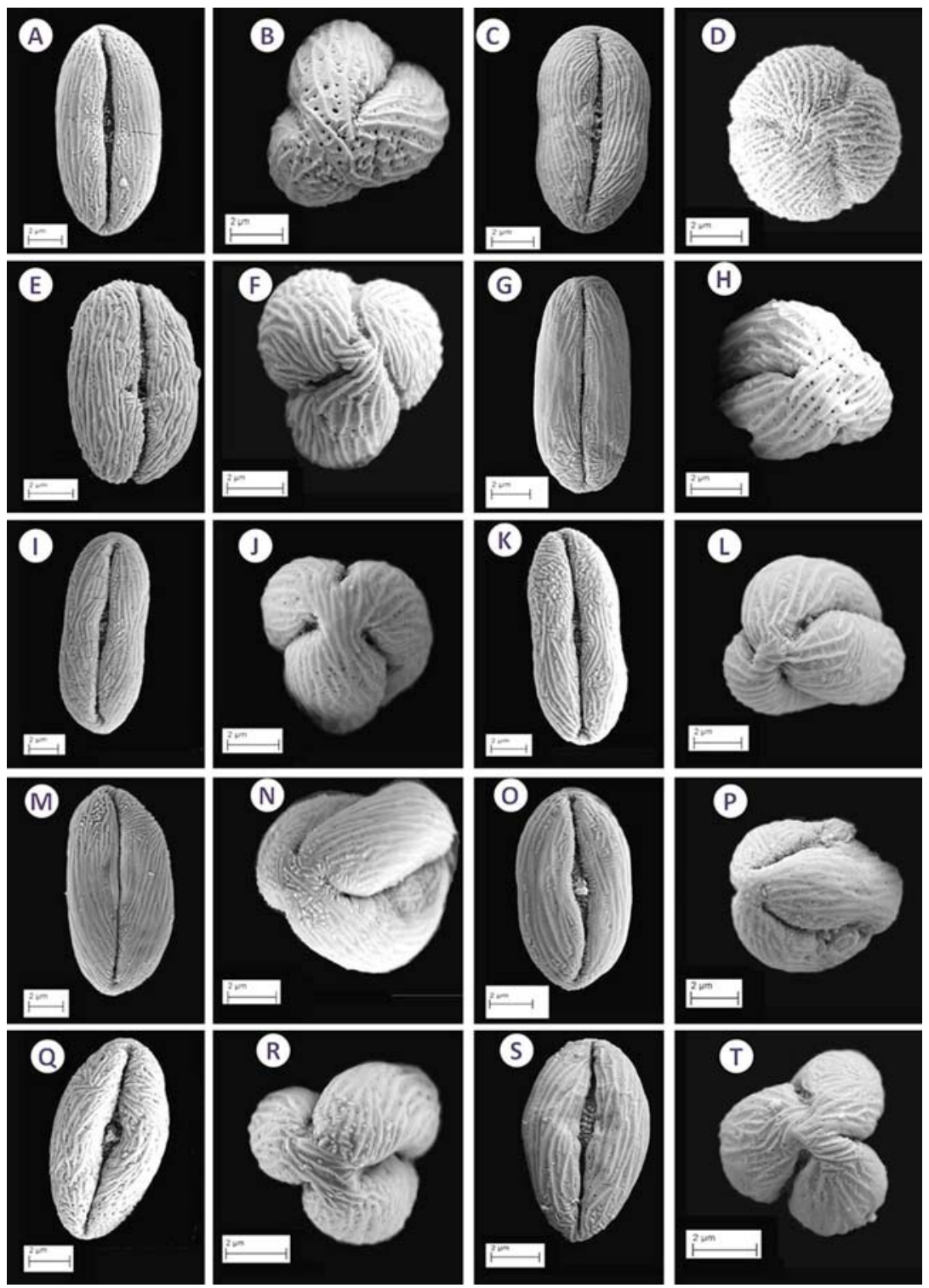

Fig. 5. Pollen in section Platycentrum, with striate ornamentation with or without pores and presence of margo. All pollens are photographes at same scale (2 $\mu \mathrm{m}$ but in different magnification). A-B. Begonia annulata (Shrestha S75); C-D. B. flaviflora (Adhikari et al. 146) ; E-F. B. cathcartii (Noshiro 9241006); G-H. B. megaptera (Kshretri 76); I.-J. B. palmata (Rajbhandary et al. S27); K-L. B. nuwakotensis (Rajbhandary et al. S31); M-N. B. sikkimensis (Rajbhandary et al. S14); O-P. B. panchtharensis (Rajbhandary S74); Q-R. B. taligera (Rajbhandary \& Adhikari S52); S-T. B. hatacoa (Rajbhandary S4).

The poles can be rounded, or somewhat pointed. The outline in polar view can be circular or rounded (B. flagellaris, B. anisanthera ined., B. flaviflora, B. manangiensis ined. and B. minicarpa), but most of the Begonia species have a somewhat triangular profile with interaxillary 
apertures (Figs 2-5). In all the taxa the ending of the colpi are acute and approach each other closely at the polar axis. Therefore, the invaginating colpi often gives a lobate impression in the polar view. Pollen with faint fine striate ornamentation shows large pores on the polar region, very clearly seen in B. dolichoptera ined. and B. josephii (Fig. 4). The pollen of B. minicarpa is totally different (Fig. $4 \mathrm{M}-\mathrm{N}$ ), with smooth spherical polar region and scattered pores and very different in shape, which separates it from other species.

Pollen grains in sections Diploclinium, Sphenanthera and Monopteron of Begonia lack margo, but margo is present in all the species in section Platycentrum (Fig. 5). From this it can be pointed out that the exine ornamentation is a more significant character than the apertures and shape of pollen to separate the sections of Nepalese Begonia.

Based on the present study, it appears that there is considerable variation in pollen morphology, especially in the exine and its sculpturing as revealed under SEM, which is of systematic value in the delimitation of some species and also sectional delimitation. Presence of margo in the pollen ornamentation is a distinguishing character that separates Begonia section Platycentrum from all other sections of Nepalese Begonia, as it is completely lacking in other sections. The observations presented here on the utility of pollen characters in section delimitation match that found in studies of African Begonia (Van Den Berg, 1984). The characters agree well with those reported earlier for Begoniaceae (Erdtman, 1966; Van Den Berg, 1984; Ma and Li, 2006).

Pollen morphology, especially the exine ornamentation, has supported placing seven undescribed species within Begonia section Diploclinium: B. anisanthera ined., B. bryophila ined. B. manangiensis ined., B. oedotheca ined., B. sinwaensis ined. (Fig. 3), B. dolichoptera ined. and B. staintonii ined. (Fig. 4) with absence of margo. This sectional placement is consistent with other macro-morphological characters of these species, especially those of the fruit and tepals.

\section{Acknowledgements}

The authors thank the curators of E, K, KATH and TUCH for allowing access to herbarium materials. We sincerely thank the staff of the Royal Botanic Garden Edinburgh (RBGE) and Frieda Christie (RBGE) especially for SEM technical support. The M.L. MacIntyre Begonia Trust, The Sibbald Trust and Fergusson Bequest and their trustees are thanked for providing financial support for this work.

\section{References}

Bano, A., Ahmad, M., Khan, M.A., Zafar, M., Sultana, S. and Ullah, Z. 2012. Pollen morphology of four endemic species of Pedicularis L. from alpine zone of the Deosai Plateau, Himalayan range. Bangladesh J. Plant Taxon. 19(1): 1-5.

Doorenbos, J., Sosef, M.S.M. and de Wilde, J.J.F.E. 1998. The sections of Begonia, including descriptions, key and species lists (Studies in Begoniaceae VI). Wageningen Agricultural University Papers, Wageningen, The Netherlands.

Erdtman, G. 1966. Pollen Morphology and Plant Taxonomy. Hafner Publishing Company, New York and London.

Erkara, I.P., Ocak, A. and Pehlivan, S. 2008. Pollen Morphology of some Turkish Campanulaceae spp. and their taxonomic value. Bangladesh J. Bot. 37(1): 33-42.

Frodin, D.G. 2004. History and concepts of big plant genera. Taxon 53: 753-776.

Hara, H., Stearn, W.T. and Williams, L.H.J. 1978. An Enumeration of the Flowering Plants of Nepal. Vol. I. British (Natural History Museum), London. p. 154.

Husseini, N.E. 2006. Pollen Morphology of Tiliaceae Juss. and Sterculiaceae Vent. and their relations to Malvaceae Juss. in Egypt. Int. J. Agri. Biol. 8(6): 844-847. 
Ma, H. and Li, H. 2006. Begonia guaniana (Begoniaceae) a new species from China. Ann. Bot. Fennici. 43 : 466-470.

Perveen, A. and Qaiser, M. 2005. Pollen flora of Pakistan-XLVII. Euphorbiaceae. Pak. J. Bot. 37(4): 785796.

Perveen, A. and Qaiser, M. 2008. Pollen Flora of Pakistan-LVI. Cucurbitaceae. Pak. J. Bot. 40(1): 9-16.

Press, J.R., Shrestha, K.K. and Sutton, D.A. 2000. Annotated Checklist of the Flowering Plants of Nepal. Natural History Museum, London.

Rajbhandary, S. and Shrestha. K.K. 2009. Begonia flaviflora H. Hara (Begoniaceae), new record for Flora of Nepal. J. Jap. Bot. 84(1): 16-18.

Rajbhandary, S., Hughes, M. and Shrestha, K.K. 2010. Three new species of Begonia Sect. Platycentrum from Nepal. Gardens’ Bulletin Singapore. 62(1): 151-162.

Smith, L.B., Wasshausen, D.C. Golding, J. and Karegeannes, C.E. 1986. Begoniaceae. Part I: Illustrated Key, Part II: Illustrated Species List. Smithsonian Contributions to Botany, No. 60. Smithsonian Institution Press, Washington.

Tamas, M., Pop, C., Martian, A. and Barbu-Tudoran, L. 2009. Morphological research on indigenous Sambucus species pollen. Not. Bot. Hort. Agrobot. Cluj. 37(1): 65-69.

Van den Berg, R.G. 1984. Pollen characteristics of the genera of the Begoniaceae. Agricultural University Wageningen Papers 83(9): 55-66.

Van den Berg, R.G. 1985. Pollen morphology of the genus Begonia in Africa. Agricultural University Wageningen Papers 84(3): 5-94.

Wodehouse, R.P. 1935. Pollen Grains. Their Structure, Identification and Significance in Science and Medicine. McGraw-Hill, New York, London.

(Manuscript received on 8 October 2012; revised on 31 October 2012) 